\title{
Historical Significances of Odaa with Special Reference to Walaabuu
}

\author{
Dereje Hinew \\ Department of History and Heritage Management, Faculty of Social Science, \\ Post Box No: 395, Wollega University, Nekemte, Ethiopia
}

\begin{abstract}
The aim of this paper is primarily to investigate the significances of Odaa (the holy sycamore tree) in Gadaa System and to underscore the significance of Madda Walaabuu in the socio-political and religious life of the Oromo. In the history of the Oromo people, the general assemblies for socio-political and religious purposes are held at the Caffee under the shade of the Odaa tree. The whole set of Gadaa political activity including Gadaa rituals, initiation, the handover of power ceremony, revising and enacting customary laws and judiciary practices are held under the shade of Odaa tree. As a result of its significance Odaa tree is honored as symbolically the most important of all trees. The close examination of people's oral tradition and the use of available written materials help us to reconstruct the history of such a theme. Written sources related to the theme were gathered and about fifteen elders of different regions in Oromia were interviewed to recollect reliable traditions related to the topic. The sources recorded were analyzed based on the historical research. The minor finding reveals that there is a deep rooted and wider range of socio-cultural and historical interpretation to Odaa (the sycamore tree). Odaa is customarily believed to be the most respected and the most sacred tree, the shade of which was believed as the source of tranquility. Shade of the Odaa was both the central office of Gadaa government where the Gadaa assembly met and was a sacred place for ritual practices.
\end{abstract}

\begin{tabular}{l}
\multicolumn{1}{c}{ Article Information } \\
\hline Article History: \\
Received : 14-02-2012 \\
Revised : 15-06-2012 \\
Accepted : 23-06-2012 \\
\hline Keywords: \\
Waaqaa \\
Odaa \\
Gadaa \\
Caffee \\
Qaalluu \\
Galma \\
*Corresponding Author: \\
Dereje Hinew \\
E-mail: qunburee@yahoo.com
\end{tabular}

\section{INTRODUCTION}

The Oromo are one of the Cushitic speaking peoples and the largest single ethnic group in Ethiopia inhabiting most areas of the country. History tells us that they had enjoyed almost a homogenous culture, a common political, religious and legal institution. They practiced Gadaa system which was an egalitarian sociopolitical and religious system. The system was the constitution of the society through which the Oromo administered, defended their territory, maintained and developed their economy. Odaa was the center for two main purposes: for religious matters where communication between Waaqaa and the society was made possible and for dealing with the socio-economic and political matters. Emphasizing on the importance of Odaa Asafa stated that "the Odaa is more than a generalized symbol of democratic discussion.... The Odaa has long been sacred meeting ground for the enactment of many Oromo ceremonies which re-enforce the political philosophy of gada (Asafa, 1998). Some of the major Gadaa centers were Odaa Nabee (East Shewa), Odaa Rooba(in Bale), Madda Walaabuu (South-Western bale), Odaa Bisil (West Shewa), Odaa Bultum(West Hararge), Odaa Bulluq (Horo Guduru) and Odaa el Dallo (Liban).

The objective of this research is to elucidate the historical attachments of Odaa to the Sociopolitical and religious life of the Oromo. There have been a number of historical and anthropological studies on Gadaa system however none of them has given emphasis to why Odaa became Gadaa Center. Hitherto, there have been misrepresentations in the discussions with regard to Walaabuu. 


\section{MATERIALS AND METHODS}

Reconstructing a history of certain theme of oral community requires a close examination of the available sources and use of oral tradition with the available written sources. All human history is Oral in origin. The contemporary value of Oral tradition in the studies of African people in general and the Oromo in particular attests the relevance oral sources. Since 1960s in Africa and in Ethiopia as well a critical use of oral sources (especially oral traditions) has made the reconstruction of people past possible. The Oromo transmit their historical and Cultural knowledge through oral tradition. The Oromo oral tradition is rich in folklore such as songs, tales legend, and myth etc. Besides, in Gadaa system the Oromo had a unique method of time computation and the method of transmitting history known as argaa-dhageettii (from what they heard and saw). Specially, the chronology and records of events based on the concept of jaatama in which one jaatama (era) consisted of 360 years or forty years repeated itself nine times helped the Oromo to retain their past and the capacity of passing their history and culture over to the generation. Moreover, systematic reference to historical and cultural studies conducted by various scholars of different disciplines helps us to reconstruct a history on marginalized themes of study.

\section{RESULTS AND DISCUSSION}

To give a thorough and comprehensive elaboration to the question why, when and how the Oromo use Odaa there is no adequate written historical sources on the early history of the Oromo. Historical and cultural studies on Gadaa institutions did not focus on the themes like the evolution of Gadaa system and the history of Gadaa centers. Bahery's book the earliest written account on Oromo history 1593 (Bahrey, 1967) had been a good source especially on the $16^{\text {th }}$ century political culture of the Oromo. However, it does not mention Gadaa centers. On the other hand, Astme Giorgis wrote that the Oromo religion had the Afro-Asiatic characteristics. He related the religion of the Oromo to Christianity that was the believe in Waaqa Gurraacha (Pure God), the veneration accorded to water and trees. In addition, Atsme indicated the fact that Walaabuu had been the political and religious center of the Oromo. He stated that the sociopolitical and religious life of the Oromo were associated with huge trees under which the Oromo used to assemble for various purposes (Bairu, 1987). However, with regard to Odaa, he referred it as something 'mysterious'. Yilma
Deressa described that the Oromo used to pray to Waaqaa (the creator) under the sacred tree and around big rivers since there were no Mosques and Churches (Yilma, 1967). Yilma's interpretation was in relation to the other religions and religious centers. The strong tradition attached to the sacred or holy areas had to be critically examined and studied.

\section{Odaa: the Holy Sycamore Tree}

Society had its own world view of how to understand this world. A society also could develop, adopt and modify cultural and political institutions. The history of such religio-political centers would be more meaningful if it is studied and interpreted as part of the world-view and historical experiences of a given society. The socio-economic, political and religious lives of the Oromo were highly intertwined which would be incomplete without investigating the origin of Gadaa system. This is because understanding the history of Gadaa centers (Odaa) requires understanding the essence of Gadaa itself. Gadaa is derived from the term gaaddisa (shelter or shade that protects from the heat of the sun). The name might have also been given owing to the democratic principles of the institution since it provided indisputable protection for the members (Gemechu, 1994). The term also has the meaning of time measurement (gadaa means eight years) and Gadaa refers to Luba a person in the Gadaa class i.e $40-48$ years (Tesema, 1980). Some historical and anthropological studies related the origin of the Gadaa system to the culture of ancient African societies mainly the Afro-Asiatic societies that shared ideas, practices and beliefs because of their common historical root (Eheret, 1976).

Various explanations were given for the reason why Odaa became a socio-political center To begin with; Odaa grows in the areas where there is abundant water, which is a source of life and fertility. Among other trees, according to the tradition, Odaa remains wet even during long period of drought. The widely told tradition claims that Waaqaa invoked spirits of dedication to big trees, rivers and big mountains and the areas were referred to as sacred. In the Oromo worldview, Waaqaa is believed to have communicated with people through intermediaries called ayyaana (spirit), which is the organizing principle (Gemechu, 1994). Hence, the sycamore tree of different kinds are regarded as an abode of spirit among the Oromo and used to provide the Oromo with ritual performances and praying site. ${ }^{13}$ For fear of retaliation, every socio- political and religious issues had to be conducted calmly and peacefully as well as based on truth. Under 
the shade Waaqaa is believed to have witnessed the denial or the agreement to be achieved. Due to the deep rooted traditional attachment to especially the sacred tree, even the reconciliations that were not held under and around the tree were not regarded as binding. (Huntingford, 1955). It appears that the tradition about the beginning of the use of Gadaa centers had more of religious background. Some scholars who were interested in religious studies argued that the life of African societies of the past was dominated by religion. Their day-to-day life and practices were interconnected with beliefs. Religion is said to have influenced the economic social, political and cultural life of individual, and the societies. As a result, the traditional African societies were referred to as "instinctively religious (Daniel, 1984).

In Africa at large, societies believing in indigenous religions related objects and living things in their environment with some other imaginary forces. Some places were given due consideration and regarded as sacred. The sacred objects and places are believed to have relations with the supernatural force. Besides, sites that attracted the imagination of religious leaders of societies appear to be the habitations of spirit. It is true that sacred areas are believed to have spirits that acted between God and human being. Here what should be noticed is that the indigenous religious believers of African societies were not worshipping the natural object but the spirit that are believed to inhabit in the natural object and that acted as intermediaries between human being and the supreme being. As G. Parrinder indicated, the worship of Supreme Being and other lesser spirits that are believed to have controlled this world was common among African societies. He mentioned that the belief of the Ashanti of Ghana in the West and the Kikuyu of Kenya in East Africa were similar in their worship of supreme being associated with sky (Parrinder, 1975).

Referring to the Cushitic tradition, Trimingham explained that the super- natural realm of local nature were associated with natural features like mountains, streams and big trees. He stated that "along with the cult of god the Cushitic believed in the existence of a whole realm of subsidiary spirits who are localized in certain trees, streams and hills". Traditionally, such areas were regarded as sacred since it is believed that the Supreme Being infused spirits to these areas. These were the appropriate places where prayers should be conducted and sacrifices were performed. More specifically, according to Trimingham, almost all
Cushitic venerated the sycamore tree. He mentioned that the Afar, Oromo, Sidama, Somali and others used to make offerings to the spirits under the sycamore tree. The general characteristics of prayers and purpose of sacrifices in such areas were mainly for rain, fertility and success in socio-economic, political and religious aspects. As one of the Cushitic peoples, the Oromo regarded sycamore tree as the abode of natural spirit (ayyaana) where spirit of Waaqaa is localized. In reference to the Muslim Yejju Oromo Trimingham indicated that:

.... They pay great attention to certain tree. There was a tree in Merse (the area is not clearly indicated) which they particularly hold in the great reverence.... They grease this tree, and perform religious ceremonies under it. Nobody dare touch or damage the tree without risking severe punishment (Trimingham, 1976).

Moreover, the Oromo conceptualization of Gadaa was related to Odaa and rooted in religious and symbolic dichotomies, which were associated to it. The Oromo had myths as well as stories that try to explain the origin of this world, the natural disasters and social disorder, the arrival of a prophet and the beginning of Gadaa system. The Oromo believed that Gadaa was a system given to them through which the people were guided and obeyed Waaqaa.

Besides, traditions explain that owing to the long period drought, only Odaa tree and spring water Walaabuu provided shade to human. All people sought the support of Waaqaa and began rain-making ritual under the Odaa tree of Walaabuu. The story demonstrates the beginning of seeking God in unity, asking God to grant the needs of the community. Because of the long time prayers, Waaqaa is said to have sent his agent Qaalluu (Nabii) from heaven. Qaalluu as a prophet came with laws of Waaqaa, rules of social order to teach human being. The first Qaalluu who is believed to have been the eldest son of Waaqaa was seen with his all insignia under Odaa tree at Walaabuu. In other words, Waaqaa visited human being in the form of Nabii under Odaa tree in prophetic time (Al Amin, 1999). A similar tradition claims that once upon a time an old innocent man called Garraamticha Walaabuu is said to have received Gadaa rules from Waaqaa in a cloud mist under Odaa tree. The old man of Walaabuu from then on became (messanger of Waaqaa who is said to have heard the whisper of Waaqaa. Hence, the myth claims that since Odaa had been the tree under which Waaqaa re-established His relation and revealed the laws, Odaa became a sacred tree of different 
Dereje Hinew

purposes. Symbolically, therefore, Odaa is a tree under which Waaqaa made reconciliation with human being.

On the other hand, observing Gadaa rules was referred to as obeying Waaqaa for the well-being of the society. For social development (guddina), cooperation in knowledge and experience had to exist. Knowledge and experience could be achieved through debate and agreement or the existence of political organization (Hinnant, 1978). Again without the existence of democracy (which elders call freedom), equality and social justice there would be no social development. Therefore, in order to achieve wholeness and peace, the balance between Waaqaa, nature, and human being should be maintained. That was achieved only by practicing Gadaa rituals and obeying Gadaa laws. Otherwise, the Oromo believed that there would be no well-being; peace (nagaa) or social development (Knutsson, 1967).The socio-political and religious matters aimed at blessing, peace and prosperity were practiced at open space under the shade of Odaa tree. The main purpose of Gadaa practitioners was to ensure health, and fertility of human beings and their animals. Rain is always the sign of blessing. In the Gadaa rituals at the Gadaa centers three elements; water (rain), grass and milk) were usually available and aimed at interconnecting the natural and social order. This is because water that comes from the sky promoted the growth of grass; the grass was food for cattle, which produced milk. During rituals or prayers, this cycle appears to be reversed: milk was powered over grass to pray for rain. This reveals that performing Gadaa rituals was aimed at achieving fertility, growth and prosperity (Huntingford, 1955).

Another myth explains that the first Odaa is said to have grown on the burial of the founding father of the Oromo. Before Odaa began to serve as a Gadaa center it was a burial center. Hence, the Oromo dealt with their socio-economic, political and religious affairs under Odaa tree at lafa dhugaa (place of truth). When people die traditionally it is said that he/she went to lafa dhugaa. It was taboo and curse to speak untruth or do wrong at the burial area of founding father where the dead could witness. It is said under the earliest Odaa tree there was a big stone that is believed to have been erected on the burial of the founding father. Similar big stones were usually placed under other Odaa trees and used during the proclamation of customary law (Mohammed, 1990). The lallabaa (the one who announces) used to proclaim the laws standing on this stone under Odaa tree. This is called dhakaa koruu, seera labsuu. It symbolized that Abbaa Gadaa and the assembly governing the society were taking oath that they would not do
Sci. Technol. Arts Res. J., April-June 2012, 1(2):81-90

wrong on the other members of the society and promise to work for peace, fertility and generally for the welfare of the society. Customarily, the shrine center is believed to have been the place where the living and the dead members of the community could participate; the former physically and the latter spiritually. It was due to such beliefs that Odaa was considered as a place of truth, sacred and used to serve as the religio-political center for the Oromo (Hinnant, 1975). Because of the historical and cultural connection, the Odaa tree had come to represent and related to the genealogical tree of the Oromo people.

A tree [Odaa] is like a human being: it has trunk and arms, it grows straight upward, and it lifts its arms to the sky like...praying. The trunk is our first ancestor and the branches are our clans and sub clans, and linages and families, and our children are like its fruits (Bartles, 1994).

The Odaa tree symbolized the relations between the past, the present and the future generation. Accordingly, the wide roots of the Odaa tree symbolically represented departed past generation. According to the interpretation based on the natural structure of the tree, the existing generation deals with their social, political and religious matters under the shade of Odaa tree by observing the law and custom of the past generation and beware not to commit sin that might affect the wellbeing of the future generation. Besides, it is believed that at open place under Odaa tree, Waaqaa easily identified who did right or wrong for the well-being the society.

\section{Walaabuu: "The Earliest Gadaa Center"}

According to some studies, Walaabuu was originally not the name of a place (Gamachu, 1994). The existing sources relate the term Walaabuu to the original water out of which Waaqaa created all creatures. In the Oromo world-view, water is considered as a primordial substance, source of life. Before Waaqaa made (creatures), there was nothing except water. Waaqaa created all creatures out of water that was known as Walaabuu. Thus, Walaabuu was the name of pre-existing water out of which Waaqaa created the first person called Horoo. Horoo is an apical ancestor who was neither male nor female. It is said that with the 'glance' of Waaqaa Horoo was divided into male and female (Haawwan) after creation in Walaabu (Bairu, 1987). In the Oromo myth of origin, Horoo was also known as Gurraacha Yaayyaa. Gurraacha refers to black (something mysterious) and purity (Lemu, 1971). 
In the Oromo oral tradition the saying 'Umeen Walaabuu Baate' reveals all creatures came out of Walaabuu. However, in a number of writings this tradition has been misinterpreted and some writers came to refer Madda Walaabuu of bale province as the origin of the Oromo nation (Dinsa, 1975). The area called Walaabuu and its environs in southern Ethiopia could be the place where the Oromo had undergone social development and emerged as an entity. Nevertheless, this geographical area does not represent the original Walaabuu.

In addition, Walaabuu is considered as a paradise (Dinsa, 1975), the original place where people lived with abundance, fertility and prosperity. It was the place where human beings were continuously given all the necessary things from Waaqaa and people lived in peace. Walaabuu is perceived as a place of righteous and purity, a place where there was no unlawful activity, no suffering, and the place of truth and generally, the place where people were governed by the laws of Waaqaa. Therefore, the original Walaabuu seems to have been more related to cosmology than to a geographical area. Another tradition claims that the Oromo progenitor was called Wolab: that was formed from mud by Waaqaa and received a living soul; and that he had his first residence at Hawaash (Negaso, 2001). Although the exact place of Walaabuu was not indicated in this particular tradition, the name Walaabuu was repeatedly mentioned as the birthplace of the Oromo ancestor. From the above views about Walaabuu, we can infer that Walaabuu and the concept about it were originally an expression of cosmology than a name of a specific place.

In other records, Walaabuu also represented the universe that consisted of the heaven, living things, and the earth including the dead. These three realities form the Oromo universe called Faajjii (banner) Oromo or Faajjii Walaabuu. The Faajjii Oromo consisted of three colors, Black, Red and White. Accordingly, heaven is Black (the symbol of Waaqaa), the living beings is red or fire, the earth and the dead in white color. The Black giant sky (Gurraacha Garaa Garbaa) symbolized the heaven in which the Oromo believe Waaqaa lived. The knowledge beyond heaven is dark. Inside the darkness existed fear and power. Waaqaa, equated with power and greatness was perceived in blackness. Red became the symbol of living beings because all living things were presumed to have blood, and it was this blood that was the symbol of life. As there was blood, there was life, and heat. Where there was no life there was no heat and fire.
When fire was out what was left was the ash and when the body disintegrated, it was reduced to skeleton (white). Both ash and a skeleton were white, all represented dead. Therefore, Faajijii Walaabuu; the Black heaven, the living thing and the material abstract fused together and give the divine, human and the dead components (Dinsa, 1975). It appears that the areas known as Walaabuu was named in the memory of the paradise.

Some studies refer Walaabuu as the earliest politico-religious center of the Oromo. There is a consensus among various scholars that Walaabuu is located in southern Ethiopia. Huntingford stated that Walaabuu or 'Tulu Walal' is located in southern Ethiopia to the west of Arsi (Huntingford, 1955). H.S.Lewis also mentioned Mount Walaabuu as the earliest homeland of the Oromo.While Haberland concluded that the cool highland Bale was the ancestral homeland of the Oromo (Lewis, 1966). Yilma reported that Haroo Walaabuu, Lake Abbaya and Hiddii Daadhii were the areas where the ancestors of the Oromo used to live. The regions north of Dawwaa River east of Lake Abbaya and areas around Ganaalee as well as Wabi Shabele were extremely fertile. These areas, which used to provide plenty pasture for the herds and flocks the Oromo used to raise were generally known as Walaabuu. The Oromo are said to have led a prosperous life in the area and the period was traditionally referred to as the "Golden age" of Oromo history (Haberland, 1963). Accordingly, since the medieval period, Walaabuu represents areas south of the Wabi River in the north, Dawwaa River in the south, Abbaya Lake in the west and large areas of eastern part of the Ganaale River in the east. Broadly speaking, the region in which the ancient Oromo shrine centers like Madda Walaabuu, Haroo Walaabuu, Mormor, Liban, Haroo Girjaa and others were located was referred to as Walaabuu.

Madda Walaabuu refers to the politico-religious center of the Oromo that is found in Dallo, in the present Bale region. It is located at about $20 \mathrm{kms}$ east of Ganaale River. The term Madda Walaabuu is said to have derived from Madda Waraabu that shows fetching water from the spring of Walaabuu (Tesema, 1980). Other related sources mention that it meant source of freedom.

The exact period when the Oromo selected Madda Walaabuu as their Gadaa center is unknown. Yet one can carefully use the data in Oromo tradition by counting generations back and some written records and attempt to give 
tentative period for such events. Taking 25 years as an average of a generation, Negaso suggested that the historical significance of Walaabuu could be 17 generations or about 400 years before the $16^{\text {th }}$ century. This dates the history of Madda Walaabuu as far back to the end of $11^{\text {th }}$ and early $12^{\text {th }}$ centuries (Negaso, 2991). A recent study on the early history of the Oromo indicated that Madda Walaabuu had become a politico-religious center in the mid- $15^{\text {th }}$ century when the Gadaa system was reformed eight years before Gadayyoo Galgaloo (ca.14561464) the first abba Gadda of the Borana. Some sources reveal that prior to Madda Walaabuu, Odaa Nabee, Katat and others located in central Shawaa were the Oromo religio-political centers. Odaa Nabee is located in southeastern Shawaa at the foot of Yerer Mountain. A recent study dates the history of Odaa Nabee as far back to 204 AD. It is said that beginning from the time that Odaa Nabee became a Gadaa center about 225 Gadaa periods elapsed. This gives us about 1800 years $(225 \times 8$ years $)$ before present. Besides, it is claimed for one jaatama (360 years) Odaa Nabee did not serve as a center and Gadaa was reformed at about $1116 \mathrm{AD}$ at the same place (Alammayyoo et al., 2004). Following the reformation with the assassination of the Spiritual leader of the Galan Oromo due to the disagreement on the reformed Gadaa rules, the Gadaa center was transferred to Odaa Roobaa at about 1316 AD. The shift of the religio political center to Odaa Roobaa was presumably caused by not only the assassination of Abbaa Muudaa of Galaan Oromo but also the pressure of the Christian Kingdom and Muslim Sultanates that were competing for territorial and religious expansion (Tadesse, 1972). It appears that the external religious pressure from both medieval Christian and Muslim states had threatened the socio-political and religious life of the Oromo groups in central Shawa.

Here, a very important point that should be noted is that Odaa Nabee, Katat, Dawaaro, Odaa Roobaa and other Gadaa centers in central Ethiopia might have served as the earliest religiopolitical centers. Some historical accounts could help us understand the early history of some Oromo groups in Shawaa. In the $13^{\text {th }}$ century, it is said that saint Takalhaymanot (ca.1215-1315A.D) conducted an extensive proselytization among the people of Galaan and Yaayyaa, who worshipped the God 'Qorke'. Yaayyaa and Galaan seem to have been the Oromo groups living in central Shawaa (Mohammed, 1994) and had established their religio-political centers at Odaa Nabee. Galaan is an important Oromo clan name, which is traditionally considered as the 'first born' (hangafa) of the northern Boorana Oromo. The Galaan and Yaayyaa were, therefore, the sedentary Oromo groups (agriculturalists) whom saint Takalhaymanot converted. On the other hand, Qorke is the name of an Oromo deity which dwells in a sacred place such as sycamore trees or any big tree, the sources of a river and etc (Alammayyoo et al., 2004).. The pastoralist Oromo groups, perhaps among the Galaan, Yaayyaa or others, are said to have moved from place to place. It appears that it was these pastoralist groups who moved to the south and shifted their Gadaa center farther south owing to the socio-political and religious insecurity in central Ethiopia.

According to Ehret, in the $13^{\text {th }}$ century when several kingdoms of highland eastern Cushitic peoples like Dawaaro and Hadiya were ruled by Monarchies, the institution of the Gadaa governed the ancestral Oromo society. Agegrade republic had served to hold together the Oromo people in a single political unit. However, the $13^{\text {th }}$ century was a time of immense political and religious upheaval and important re-ordering of relations of power. It is said that the entire region around the upper drainage basin of the Awash became the focal point of intense struggle for political power and access to commerce. (Mohammed, 1994). More significantly, however, the socio-political and religious life of some Oromo groups might have been affected in the $14^{\text {th }}$ century. The emergence of powerful Christian Kingdom with economic, political and religious ambitions did not remain without affecting the lives of the Oromo living in central Shawaa. As Negaso stated, the religio-political center of the Oromo during the reign of Amdetsion (1314-1344) is given as Katat. It was then transferred to Dawwaro during the same period; from Dawwaro the center moved to Odaa Nabee and remained there for a longer time (Negaso, 2001).

Dawwaro is indicated to be in northeastern Shawaa and it is claimed that Dawaaro was the homeland of Laaloo. The reason for the shift of the religio-political center was the attack of Amdetsion. The seven sons of Laaloo are said to have been driven away from Katat and Dawaaro in the reign of Amdetsion. This view might reflect the actual flight of some Oromo groups from Dawaaro and Katat. As a result of the social, religious and political insecurity, the indicated Oromo groups might have been forced to shift their religio-political center farther to the south (Negaso, 2001). It seems that these Oromo groups were restricted to use Odaa Roobaa and Madda Walaabuu. 
For about Nine gadaa periods (72 years) 1384 1456) before Gadayyo Galgaloo it is said that there was no Gadaa government and the time was the period of uncertainty (bara dukkana) (Alemayehu,et al,2004) However, following the reformation of Gadaa (in ca.1445) the site of Gadaa assembly was named Madda Walaabuu (meaning source of freedom). The purpose of reforming Gadaa system was to defend the territorial expansion and pressure of the Christian kingdom at the time. It is suffice to recall the fact that by early 1440s King Zarayaqob (1434-68) had exerted pressure on south and south east medieval societies (Mohammed,1994). It was the 1440s Gadaa reformers at Madda Walaabuu that came to call their Gadaa center Madda Walaabuu being divided into confederacies of Borana and Barentuu.

From the point of view of the Oromo people, the concept of the origin of the nation and sociopolitical as well as religious development are attached to Madda Walaabuu. Tradition refers to it as the basic religious and socio-political center. Madda Walaabuu, as an original settlement, marked the sacredness of the place where the founding father of the society originated and used to live. It seems that the place was given this name for the memory of the original Walaabuu. In the Oromo genealogical tree, there was one founding father called Walaabuu, the son of Odaa and the father of Raayya. Perhaps also, Madda Walaabuu might have been founded by a person called Walaabuu (Tesema,1977). The original residence of the founding father or clan leader (ancestor) could gain superiority as a common place of meeting and becomes a shrine symbolizing the unity of the nation. It could become the society's sacred meeting place and during their assembly, they were able to solve their social, political and economic problems. The connection of the name of the area to the original Walaabuu seems to have been aimed at bringing a sense of oneness or belongingness to the same founding father.

The Oromo, before and after their dispersion into different confederacies had common Central Caffee at Madda Walaabuu. The Oromo are said to have lived in the highlands of southern Ethiopia and historical Bali region for long. There, the Oromo are said to have shared a common language, culture, custom and law, 'a government' and institutions such as the office of the Abbaa Gadaa and Qaalluu (Mohammed, 1990).

\section{Madda Walaabuu: Central Caffee (ca. 1445-1900)}

Madda Walaabuu is said to have been the Central Caffee of the Oromo. Caffee or gumii refers to the parliament in which legislative and judiciary powers were held. Caffee was a grassy plain on which an open-air assembly of the council and the handover power ceremony and others were held. The national (the pan-Oromo) assembly was held under Odaa Walaabuu and it was known as Caffee Oromo (Oromo parliament) (Lemu, 1971). Thus, Caffee stands for the assembly place where the most important ceremonies were performed, where all important decisions were made, where laws were formulated and judgments passed by the ruling Gadaa class (Knutsson, 1967). It was at the Caffee assembly that old laws were revised and new legislations were introduced by the Gadaa council every eight years. Asmarom has given a more basic definition of the general assembly in terms of its range of activities and its relations to other Oromo institutions. As he stated:

The national assembly, (Gumi or Chafe) is made up of all the assemblies and councils of the Oromo who meet in the middle of the Gada period once every eight years to review the laws to make new laws, to evaluate the men in power and to resolve major conflicts that could not be resolved at lower levels of their judicial organization (Lemu, 1971).

Historical records indicate that the foundation of traditional Oromo law was laid down at Madda Walaabuu (Dinsa, 1975). The ancient Oromo law is said to have been elaborated by five founding fathers (Yaayaa Shanan). These Abbootii Seeraa (fathers of the laws) were Boruu Biloo, Gallee Anno, Maane Leeqaa Jaarsoo, Goloo Gobbu and Baabboo Galleessa (Gemachu,1994). The founding fathers are said to have formulated the rules governing such issues as the animal world both domestic and wild, the position of man in society and methods of time computation (Gemachu, 1994; Mohammed, 1990). The laws laid down by the five founding fathers seem to deal with the general principles in the various areas of law rather than with the specific legal cases. It seems that the specific laws were developed because of customary practices through time.

In the Oromo customary law, there are two distinct terms aadaa (custom) and seera (law). The former is known to individuals who belong to the same culture while the latter is only known to who specialize in it (Dinsa, 1975). Aadaa refers to 
custom, habit, tradition, way of life etc. and was a symbol of identity, unity and oneness. It is believed that the laws of human beings were derived from the laws of Waaqaa. They are believed to have been revealed to human being through prophets who are said to be able to hear "the whisper of God". Waaqaa is regarded as the ultimate source of all laws (Gemechu, 1994).

In the traditional process of law making, among the Oromo in general dhugaa ganamaa "the justice of day break" also seems to have been source of Oromo customary law. It is said that dhugaa ganamaa served the Oromo law as a checkpoint to return to true justice. "The justice of day break" is considered as a fair and just law, clean and unspoiled and it is a justice given at the beginning of human history. According to the tradition, dhugaa ganama is equivalent to the concept of natural law (Dinsa, 1975). The laws and principles of the Gadaa system known as Seera Caffee Oromo or Seera Walaabuu are said to have been formulated at the central Caffee and have been the basis of Oromo customary laws. The most common laws enacted at the Central Caffee refer to the socio-political, economic and religious life of an individual Oromo. Seera and aadaa are highly integrated and the former protects the latter.

As a constitution, Seera Caffee Oromo, generally included Seera Eebbaa (blessing law), Seera Biyyaa (the law of the country), Seera Bultii Birmadaa (law of persons), Seera Yakkaa fi Balleessa (criminal and civil laws) and etc. One of the most important parts of Seera Caffee Oromo is the law of the country (Dinsa, 1975). The social, political and religious rules and regulations of the Gadaa System are known as Seera Biyyaa. It applied to the whole Oromo nation as they used to live under the same system of administration or the caffee government of Madda Walaabuu. Seera Biyyaa consisted of laws concerning individual duties and responsibilities in the society that was determined by the Gadaa assembly. Besides, the powers and authorities of lubaa office, law proclamation, and religious power of the Qaalluu and the laws of Walaabuu as sacred place were the main bodies of Seera Biyyaa (Dinsa, 1975). The Seera Biyyaa also puts emphasis on the executive, judiciary and legislative offices authority and tenure of their period. The Seera Biyyaa allowed individual Oromo to get power after fulfilling all the necessary Gadaa rituals and requirements needed. It is Seera Biyyaa (as Gadaa rules) which taught members of different Gadaa class that they were subject to removal when the fixed period is terminated (Gemechu, 1994). One of the interesting aspects of Seera Caffee Oromo since ancient times was that it put the Abbaa Muudaa (spiritual leader) as the guider of the customary law and source of laws. The offices of Abbaa Gadaa and Abbaa Muudaa had been in the same area at Madda Walaabuu. Seera Biyyaa also had laws for the Abbaa Muudaa. Accordingly, the purity, taboo and responsibilities of Abbaa Muudaa were dictated by the Seera biyyaa.

The ancient law of the Oromo that is said to have developed into Seera Caffee Oromo made everything move with ease and care, in peace and order since the dawn of Oromo history. The presence of Qaalluu helped the Gadaa System of government to work properly. It had contributed to the existence of balance of power and mechanisms of succession that sustained social order. It is said that it was the ancient law of the Oromo or Seera Walaabuu that gave the Qaalluu the right to sit with the Gadaa leaders in a forum and discuss matters of common interest that concerned the Oromo people. The Abbaa Muudaa is said to have been the main participant of the pan-Oromo assembly at Madda Walaabuu every eight years when changes and new ideas were raised and checked against the cherished traditional values (Dinsa, 1975). Before changes in law took place, the Abbaa Muudaa and the Gadaa leaders had to discuss the laws quite deeply, make valuable changes and promote the dissemination of the laws throughout Oromoland. The belief that the ancient Oromo law was derived from the laws of Waaqaa and that Abbaa Muudaa was the representative of Waaqaa on earth had symbolized Abbaa Muudaa as the father of all Oromo and source of Oromo laws.

The main function of law was protecting custom. The laws of sacrifice, prayer and blessing that were performed used to govern the relationship between man and divine. The laws binding man and Waaqaa determine the proper performance of rituals (Gemechu, 1994). Other laws like Seera Birmadaa (law of persons), Seera Rakkoo (law of marriage and divorce) and criminal and civil laws were also part of Oromo constitution. Although the Yaayaa Shanan (the five founding fathers) do not seem to have laid down this specific and detailed laws, it appears that criminal and civil laws were parts of Seera Caffee Oromo since ancient times. The place of an individual in the society is said to have been laydown by the founding fathers at Walaabuu. Seera Caffee Oromo had prescribed sanction measures and punishing laws. The criminal and civil laws are said to have included death penalty, payment of blood price with or without peace 
settlement ceremony, exile, exclusion from association, compensation, corporal punishment condemnation of the wrong doers, asking pardon and others. Even though the laws were there, it is said that death penalty and corporal punishment were rarely applied. Most of wrongs were redressed in the form of compensation (gumaa) and all wrongs were dealt with on a system of mediation. Therefore, Madda Walaabuu was a sacred place where the ancestors of the Oromo laid down the basic Oromo laws.

Therefore, the local Gadaa centers used to take laws from Madda Walaabuu and acted under the Gadaa assembly of the Central Caffee. According to elders, the similarity of Gadaa rules and regulations among the different Oromo groups was because of the fact that the base of their socio-economic political and religious life was Seera Caffee Oromo. Madda Walaabuu is also said to have been the place where the ancestors of the Oromo took oath. This oath is permanent and it is known as Kakaa Oromo (the Oromo oath). The Oromo oath was the great rule of law, which prescribed that an Oromo shall not kill another Oromo. It was a great norm that kept the Oromo unity. It appears that Kakaa Oromo was initially aimed at unifying the Oromo under one system of government and work for common interest (Dinsa, 1975). Obeying the common law brought a sense of unity, identity and common internal peace. Both literature and oral tradition do not precisely indicate the time when Kakaa Oromo was made. Nevertheless, the event might coincide with the foundation of Seera Caffee Oromo. Its importance in the Oromo sociopolitical life was so tremendous. It is said that Kakaa Oromo that was enacted at Madda Walaabuu prohibited the killing of an Oromo by another Oromo, and reserved the Oromo unity for a long period. Even in the later days after the formation of confederations and establishment of new religio-political centers and during inter-clan or individual fighting, individuals used to fight with bent spears so as not to inflict fatal wound or kill his or her brother. Kakaa Oromo has been very strong among the Boorana, the Gujii Oromo and other Oromo groups who have preserved the Gadaa system and Seera Caffee Oromo.

The great assemblies of various Oromo groups at different Gadaa centers used to act in the model of this Central Caffee of the Oromo. The Central Caffee at Madda Walaabuu had the power to legislate for the caffee under the confederacies. New laws were promulgated and amended as well as the old laws were revised by the central assembly. Furthermore, the Caffee assembly at Madda Walaabuu was concerned with very critical and important issues like war and peace, legislation, peace resolution in the disputes hearing cases that were brought from the lower Gadaa assemblies. Therefore, the Central Caffee at Madda Walaabuu remained to be the source of customary laws for the lower assemblies, which were modeled based on the broader and bigger government of Central Caffee. Every eight years the lower Gadaa assemblies used to receive the revised and enacted laws through their representatives. The delegates who participated on the national assembly at Central Caffee are said to have brought the laws to their localities (Mohammed, 1990; Tesema, 1984). This continued until the end of $19^{\text {th }}$ century when pan-Oromo assembly was suppressed for fear of rebellion against the government of Menelik.

\section{CONCLUSIONS}

In the Oromo world view, the traditions attached to the evolution of Gadaa and the beginning of the use of the shade of Odaa are highly intertwined which has religious social and political concepts. Hence, it would be difficult to give a separate meaning to the sycamore without understanding the Concept of Gadaa system. On the other hand, the finding reveals that originally the term Walaabuu has a concept of paradise, a place of blessing fertility, prosperity etc. The Gadaa center Madda Walaabuu was named in the memory of this paradise and as the term reflects it was a panOromo parliament that might have been established in $14^{\text {th }}$ century to defend the growing pressure of the medieval Christian state. Prior to Madda Walaabuu, Odaa Nabee and other Gadaa centers might have served as a socio political center. Historical data claim that at Madda Walaabuu the Oromo experienced tremendous civilizations in the legal and sociopolitical as well as religious life. Broadly speaking, Madda Walaabuu served as a societal socio-political center unit the decline of Gadaa government in the second half of the nineteenth century.

\section{REFERENCES}

Al Amin Sheytu. (1999). Gada System: Nature, Operation, Constraints with reference to the experience of Guji Oromo, Department of Political Science, Addis Ababa University.

Asafa Jalata. (1993). Oromia and Ethiopia: State Formation and Ethno- national Conflict, 1868-1992. Lynne Rienner Publisher, Boulder. 
Dereje Hinew

Asmarom Legesse. (1954). Oromo Democracy: An indigenous African Political System. The Red Sea Press, 2000.

Bahrey. The History of Galla In: C.F. Beckingham and G.W.B Hunting ford. Some Records of Ethiopia (1593-1646). Hakluyt Society, London.

Bairu Tafla. (1987). Atsma Giyorgis and His work." History of the Galla" and the kingdom of Sawa. Stuttgart, Franc Steiner Verlag Wiesbaden GMBH.

Bartles Lambert (1990). Oromo Religion, Myth and Rites of the Western Oromo of Ethiopia. An Attempt to Understand. Dietrich Reimer Verlag, Berlin.

Bartles, Lambert. (1994). On Pilgrimage to a holy tree. A River of Blessing: Essays in Honor of Paul Baxter. David Brokensha, (ed.) Syracuse, N.Y: Mawell School, Syracuse University.

Beckingham. C.F., Hunting Ford G.W.B. (1954). Some Records of Ethiopia 1593-1646). Hakluyt Society, London.

Blackhurst Hector. (1978). Continuity and Change in Shoa Galla Gada System. Age, Generation and time: Some Features of East African Age Organization, Baxter P.T.W. and Uri Almagor.

Braukamper Uirich. (1980). Oromo Country of Origin, A reconstruction of Hypothesis. Six in International Conference of Ethiopian Studies, Tel- Aviv.

Daniel Ayana. (1984). Protestant Mission in Wallaga, A study of the activities of the Missions and the local converts 1898-1935. Department of History. Addis Ababa University.

Dereje Hinaw. (2000). A History of Odaa Bulluq, Department of History, Addis Ababa University.

Dereje Hinew. (2005). Historical significance of some major gadaa centers in Oromia, Department of History, Addis Ababa University.

Dinsa Lapiso., Abba Jobir. (1975). The Gada System of Government and Sera Chafe Oromo. National University. Addis Ababa.

Ehret Christopher. (1976). Cushitic pre-history, The Non Semitic Languages of Ethiopia. M.L Bender (ed.), East Lansing, Michigan State University.

Ehret Christopher. (2002). The Civilization of Africa: A history to 1800 . University Press, Verginia.

Feyisa Demie. (1998). The Origin of the Oromo. A reconsideration of the theory of the Cushitic Roots. The Journal of Oromo Studies 5(1\&2): 155-172.

Gada Melba. (1988). Oromia: An introduction. Khartoum, Sudan.

Gemechu Megersa. (1994). Knowledge, identity and the Colonizing Structure: the case of the Oromo in East and North east Africa, PhD Dissertation, School of Oriental and African Studies, University of London.

Haberland Eike. (1963). Galla- Sud-Athiopiens Stuttgart, Kohl hammer.
Sci. Technol. Arts Res. J., April-June 2012, 1(2):81-90

Haberland, Eike. (1964).The influences of the Christian Ethiopian Empire on southern Ethiopia. Journal of Semitic studies 9:235-244.

Hinnant John Tomas. (1975). The Gada System of the Guji of Southern Ethiopia, PhD Dissertation.

Huntingford. G.W.B. (1955). The Galla of Ethiopia: The Kingdom of Kaffa and Janjero. Ethno graphic Survey of Africa. International African Institute, London.

Knutsson, K.E. (1967). Authority and Change: A Study of the Qallu Institution among the Mecha Galla of Ethiopia. Gothenburg.

Lemu Bayisa. (1971), The Democratic Political System of the Galla of Ethiopia and the Possibility of its use in the Nation building. USA George Washington University.

Levin, D.N. (1964). Greater Ethiopia: The Evolution of a multiethnic society. London.

Lewis, H.S. (1966). The Origin of the Galla and Somali. Journal of African History 7(1):27-46.

Mbiti, J.S. (1975). An Introduction to African Religion. London.

Mbiti, J.S. (1990). African Religion and Philosophy. Oxford ports mouth, Heinemann.

Mindaye Abebe. (2005). The Oromo of Bale: A Historical Survey to 1974. Department of History, Addis Ababa University.

Mohammed Hassen. (1990).The Oromo of Ethiopia. A history, 1570-1860. Cambridge.

Mohammed Hassen. (1994). The pre-sixteenth Century Oromo presence in the Medieval Christian Kingdom of Ethiopia. In: Rivers of Blessing Brokensha. D (ed.). African Series, Syracuse University.

Negaso Gidada. (2001). History of the Sayyo Oromo of South Western Wallaga, Ethiopia from about 1730 to 1886. Mega printing Enterprise, Addis Ababa.

Parrinder, G. (1975). African Traditional Religion. $3^{\text {rd }}$ edition, London.

Tadesse Tamirat. (1972). Church and State in Ethiopia, 1270-1527. Oxford Studies in African Affairs. Oxford.

Tedecha Gololcha. (1998). The Politico-legal System of the Guji Oromo, B.A. Thesis, Faculty of Law, Addis Ababa University, Addis Ababa.

Tesema Ta'a. (1977). The Oromo of Wallaga: A Historical Survey to 1910. School of Graduate, Addis Ababa University.

Trimingham. (1976S). Islam in Ethiopia. Frank case and Company limited, London.

Yilma Deressa. (1967). Ye Itopiya Tarik Be Asra Sidestegnaw Kifle Zemen. Addis Ababa. 